\title{
УЧЕЊЕ СТРАНОГ ЈЕЗИКА КАО ИЗАЗОВ ЗА ,ДРУГАЧИЈЕ ИНТЕЛИГЕНТНУ“ ДЕЦУ И НАСТАВНИКЕ: ИНКЛУЗИВНО ОБРАЗОВАЊЕ И ИНТЕРКУЛТУРНИ ПРИСТУП
}

\section{Сажетак}

Разумевање и прихватање инклузивних вредности требало би да одликује наставу XXI века и свакако представља један од изазова с којима се суочава савремена настава страног језика. Полазећи од питања како постићи квалитетно образовање за свако дете, као и за сваког наставника, укључујући и тзв. осетљиве групе, и стављајући акценат на рано интелектуално сазрелу децу, на рано и почетно учење страног језика из перспективе интеркултурног и плурикултурног приступа, заснованог на истим вредностима као и инклузивно образовање, у раду разматрамо могућности подстицања активног учешћа као предуслова за учење и напредовање. Примери могућег вођења ученика и укључивања у рад, као и подржавања њихове самосталности, намењени су професорима француског језика, али су методолошки употребљиви на часу било ког страног језика. Учење страног језика кроз креативно-уметничке активности, њихово освешћивање и пружање повратне информације помаже деци да, упркос развојним и/или друштвено-егзистенцијалним проблемима, граде и доприносе заједничким активностима, да доживе учење као вредно труда, при чему је драгоцена подршка околине и наставника чија очекивања треба да буду непритискајућа али све већа. Час страног језика могао би се посматрати као обогаћујуће хумана пустоловина која доприноси личном развоју свих учесника у наставном процесу. Рад води закључку да је стога потребно у иницијалном и континуираном образовању наставника развијати свест о условима и ефикаснијим стратегијама за постизање резултата различитих ученика, о предности коришћења различитих приступа а нарочито оног који учење види као креативно решавање изазова (боље него „проблема“), о избору одговарајућих предложака и стварању подстицајног амбијента за учење, као и о потреби стварања интеракција у којима је свако и учитељ и ученик.

Кључне речи: инклузивно образовање и обучавање, интеркултурни приступ, интелектуално рано сазрела деца, различитост, француски као страни језик.

*3brajo@eunet.rs 


\section{Увод}

У нади да пружамо скроман допринос размишљању будућих наставника страног језика, али и наставника практичара, оптерећених крупним и разноврсним захтевима које пред њих поставља савремено друштво и (инклузивна) школа, у првом делу текста указујемо на актуелну теоријску мисао у области образовања (методике, психологије и педагогије), да бисмо у средишњем делу изнели предлог могуће истовремене примене инклузивног и интеркултурног приступа, с конкретним предлошцима намењеним узрасту од дванаест година и с поглављем посвећеним специфичностима „рано интелектуално сазреле деце“. Циљ рада је, дакле, показати, применом експлоративно-интерпретативног поступка, како је једно од решења за рад са децом која имају посебне потребе примена интеркултурног приступа у настави страног језика, уз континуирано образовање наставника ради педагошког прилагођавања специфичностима ученичких потреба. Рад завршавамо истицањем важности образовања наставника још у оквиру факултетске наставе, која од њих не може да направи инклузивне практичаре али може да развије свест о изазовима савремене наставе и значају подржавања самопоштовања и самопоуздања „другачије интелигентне“ деце, као јединог пута ка њиховој самосталности и обостраном задовољству ученика и наставника у инклузивној школи.

Једно од основних питања савремене наставе уопште, па и наставе страног језика, јесте како постићи инклузивно односно квалитетно образовање за сву децу, омладину и одрасле, што значи и за сваког наставника (Холенвегер 2015, 61), укључујући и „осетљиве“ групе ученика, „угрожене“, „маргинализоване“, то јест групе којима је потребна додатна подршка у образовању. Према класификацији Организације за економску сарадњу и развој (Organisation for Economic Co-operation and Development), коју користи Завод за вредновање квалитета образовања и васпитања, реч је о ученицима: са сметњама у развоју и инвалидитетом (телесни инвалидитет, моторичке, чулне, интелектуалне, комуникацијске сметње); са специфичним тешкоћама у учењу (у овладавању вештином читања, писања или рачунања, с проблемима у понашању или у емоционалном животу); с проблемима који проистичу 
УЧЕЊЕ СТРАНОГ ЈЕЗИКА КАО ИЗАЗОВ ЗА „ДРУГАЧИЈЕ ИНТЕЛИГЕНТНУ“ ДЕЦУ И НАСТАВНИКЕ: ИНКЛУЗИВНО ОБРАЗОВАҢЕ И ИНТЕРКУЛТУРНИ ПРИСТУП

из социјално-економски нестимулативне средине (у ову групу спадају и деца чија породица не говори језиком на којем се одвија настава, или језичке мањине). Иако се у наведеној класификацији не помињу експлицитно „надарени“ ученици, за које се све чешће предлажу прикладнији називи - ученици са „високим/ јаким потенцијалом“, „високо мотивисани“ ученици, ${ }^{1}$,интелектуално рано сазрели“, извесно је да они припадају деци којима је потребна посебна подршка (Бут и Ејнскоу $2010,11)$. Реч је о деци која су „другачије интелигентна или надарена“, нарочито на вербалном плану, чија је интелигенција квалитативно другачија а не квантитативно већа, и која неретко имају проблеме у школи. Француски психолог Факшен (2015) их назива „необичним зебрама“, алудирајући на јединствене карактеристике (пруге, међусобно различите) и могућности за „белу“ или „црну“ будућност, истичући такође њихову осетљивост и потребу да се стопе с околином, закамуфлирају своју особеност. То је управо група ученика коју у овом тексту првенствено имамо на уму предлажући садржаје, активности и приступе.

Акценат стављамо на високо мотивисане ученике из неколико разлога. Осим што имамо мало искуства у раду с осталим групама осетљивих ученика, сматрамо такође да се ова група ученика не сме занемарити у раном учењу страног језика, што је тема која је иницирала писање овог текста. У прилог одабраном становишту иду и излагања дечјих психијатара, неуропсихијатара и психолога (Револ 2015; Факшен 2015) који сматрају да је познавање начина на који функционише мозак надарене деце, као и узрока њихових проблема у школи, уједно и пут разумевања проблема све деце с тешкоћама у учењу и комуникацији с другима.

1 Израз „високо мотивисани ученици“ чули смо од Вигора Мајића, директора Истраживачке станице „Петница“, који нас је и мотивисао да о овој групи ученика размишљамо својим поздравним говором приликом семинара (2123. април 2016) за методичаре наставе на факултетима на тему савремене инклузивне теорије и праксе, посвећен модернизацији студијских програма за будуће наставнике. Скуп је организован у оквиру пројекта „Савремена пракса у образовању наставника за различитост“, који реализује Истраживачка станица „Петница“ у сарадњи са Министарством просвете, науке и технолошког развоја и Уницефом, а водила га је проф. др Јудит Холенвегер (Judith Hollenweger) са Педагошког института Универзитета у Цириху. 


\section{I Савремена теоријска мисао о настави страног језика: различитост као изазов}

„Различитост“ је једна од кључних речи у савременој теоријској мисли о настави страног језика, било да је реч о инклузивном образовању, интеркултурном приступу, плурилингвизму или плурикултурализму, што су појмови које у овом поглављу укратко објашњавамо указујући на њихову сродност.

„Инклузија“ значи поштовање потребе и права свих ученика на учешће, подршку и адаптацију, то јест потпуну укљученост у вршњачки рад, нарочито осетљивих група:

Инклузија у контексту образовања се односи на процес одговарања на различитост са циљем превазилажења препрека за учење и учешће са акцентом на оне групе ученика који могу бити изложени маргинализацији, искључивању и постигнућима испод својих могућности. (Европска агенција 2013, наведено према Холенвегер 2015, 61)

Све осетљиве групе ученика имају неколико додирних тачака: осећају се другачијим и одбаченим, нарочито у вишим разредима основне школе; окружење често не допушта да развију своје способности, или те способности не препознаје и не разуме, па самим тим и не признаје, тако да нема ни адекватне подршке; међусобно се препознају, а није ретка појава да „најталентованији“ ђаци желе да помогну осталим категоријама „угрожених“ ученика. Како наглашавају стручњаци у области инклузије, као Бут и Ејнскоу $(2010,7,10)$ или Холенвегер, инклузивно образовање подразумева „сагледавање разлика међу ученицима као ресурса за подршку учења, а не као проблема које треба превазићи“ (Холенвегер 2015, 63). Таква, позитивна перспектива кључна је за рад у инклузивној школи и примену њених принципа, и на њој треба радити како са будућим наставницима и наставницима практичарима, тако и са ученицима.

Наставницима би, такође, ваљало скренути пажњу на идентичност инклузивних и принципа савремене теоријске и језичко-политичке образовне мисли, односно на предност примене интеркултурног, плурикултурног и плурилингвалног приступа у настави и учењу 
УЧЕЊЕ СТРАНОГ ЈЕЗИКА КАО ИЗАЗОВ ЗА „ДРУГАЧИЈЕ ИНТЕЛИГЕНТНУ“ ДЕЦУ И НАСТАВНИКЕ: ИНКЛУЗИВНО ОБРАЗОВАЮЕ И ИНТЕРКУЛТУРНИ ПРИСТУП

страних језика. Реч је о вредностима за које се још од 60-их година прошлог века залажу Савет Европе и његове институције, ${ }^{2}$ а то су, укратко, очување и богатство разноликости, културне, језичке и сваке друге, учење језика, толеранција и дијалог.

Термин „интеркултурно“ први пут се помиње у Француској средином 70-их година прошлог века, откад се унутар Савета Европе воде дискусије у вези са интеркултурним дијалогом, напуштањем етноцентризма и образовним проблемима деце миграната. У вези са учењем француског као страног језика јавља се средином 80-их година (Шародо 1987), а о концепту интеркултурне компетенције пишу лингвисти и дидактичари Абдала-Претсеј и Порше (2001), Абдала-Претсеј (2004), Зарат (2003), Де Карло (1998), систематизује Жан-Мишел Робер (2009). У последњој деценији XX века формулише се „интеркултурни приступ“ (Дурбаба 2011, 49), који подразумева компаративни поступак и игру „укрштених погледа“, као и поштовање различитости другачијих култура. Уз „плурилингвизам“ и „Плурикултурализам“, „интеркултуно“ је једна од кључних речи Зајеgничкої евройскоі оквира (ЗЕО) (Савет Европе 2003), референтне публикације у домену савремене наставе страних језика. Иако се термини „Плурилингвално“ и „плурикултурно“, као и „мултилингвално“ и „мултикултурно“ често користе као синоними, у овом раду прихватамо значење „мултилингвизма“ као равноправно коришћење више од два језика у некој држави, друштву, граду, а „плурилингвизма“ као индивидуално познавање три или више језика (Робер 2009, 71). Мултикултурални приступ често се зауставља на пукој констатацији да постоје културне разлике, за разлику од интеркултурног који има за циљ превазилажење тог стадијума, односно успостављање дијалога са другим, „дакле учење сусретања (а не учење културе другога)“(Робер 2009, 102-103). По Кристијану Пирену (2002), појам интеркултурности се данас све више користи да означи умеће суживота (vivre ensemble) у савременом западном друштву, те овај дидактичар ствара нови термин „кокултурно“, говорећи о „заједничком стварању, упркос и захваљујући нашим различитостима“ (Пирен 2002), а што се у

2 Мислимо првенствено на Евройски иенийар за живе језике (European Centre for Modern Languages/Centre européen pour les langues vivantes) у Грацу. 
настави страног језика развија подстицањем ученика на реализацију сложених задатака, пројеката.

После десетогодишњег рада на коначној верзији Зајеgничкоі евройско̄ оквира, његови аутори такође подвлаче значај језичке и културне разноликости не само због „изградње лингвистичког и културног идентитета интегрисањем различитих искустава других људи и култура“ него и због ,развијања способности учења кроз то исто разноврсно искуство прожимања различитих језика и култура“ (ЗЕО 2003, 149).

Када је реч о раном учењу страног језика, Порше и Гру (1998, 54) проналазе званични документ из 1995. године у којем се указује на чињеницу да оно доприноси отворености ка другости и бољем разумевању другога. Сходно заједничким вредностима инклузивног образовања и савремене глотодидактике, ученике је још у раном и почетном учењу страног језика пожељно (забавним активностима) подстаћи да схвате да су сви у исти мах исти, једнаки али и различити, јединствени, те да различитост треба доживети као повољну прилику за богатије и разноврсније заједничко учење. У ту сврху, с млађом децом могле би се користити сликовнице на тему различитости и сличности, којих у XXI веку има све више и имају за циљ да децу уче толерантности и хуманости, ${ }^{3}$ а за све узрасте такође постоје књиге са лудичким активностима за развијање емоцчионалне инйелиіенције. ${ }^{4}$ Како би се живело и радило са другима, како би се стекло поверење у себе и друге, како би се ишло путем самосталности и креативности, управо на емоционалној интелигенцији треба радити са свом децом, а нарочито са интелектуално рано сазрелом, будући да је њихова слаба тачка владање емоцијама.

Овај све „популарнији“ вид интелигенције у савременом друштву може се повезати с Гарднеровим двема инйелиіенцчијама инйрайерсоналном и инйериеерсоналном, али и са појединим препору-

3 На часовима француског као страног језика, у недостатку материјала урађеног за ученике страног језика, могле би се користити сликовнице које су намењене изворним говорницима, чак и нешто млађег узраста, с обзиром на слабији језички ниво, као на пример: Пар (2006), Мансо (2008), Димон (2007).

4 На пример активност “Des choses en commun» из књиге Éducation émotionnelle, de la maternelle au lycée (Клајс 2014). 
УЧЕЊЕ СТРАНОГ ЈЕЗИКА КАО ИЗАЗОВ ЗА „ДРУГАЧИЈЕ ИНТЕЛИГЕНТНУ“ ДЕЦУ И НАСТАВНИКЕ: ИНКЛУЗИВНО ОБРАЗОВАЮЕ И ИНТЕРКУЛТУРНИ ПРИСТУП

кама из Оквира. Као што је познато, Гарднерова теорија о вишеструким интелигенцијама (Гарднер 1983) једна је од референтних теорија савремене акционе перспективе у настави страног језика и Зајеgничкої евройской оквира, што се најбоље види у поглављима посвећеним потреби за развијањем оититих иняивияуалних комиееиенција (2.1.1; $5.1 .3,5.1 .4)$, а нарочито оном посвећеном способности отворености за учење (savoir-apprendre), које се може схватити и као „'отвореност за упознавање другога', било да је то друго неки нови језик, нова култура, нова особа или нова сазнања“ (ЗЕО 2003, 20), односно способности „посматрања, учествовања и интегрисања нових искустава, и спремности за мијењањем претходних“ (3ЕО 2003, 120, подв. у оригиналу). Ових неколико страница у Оквиру, које заправо говоре о развијању ученикових стратегија учења али и о изграђивању свести да је учење страног језика ново, обогаћујуће а не угрожавајуће искуство, сматрамо изузетно важним за иницијално и континуирано образовање наставника страног језика за инклузивну праксу. Оне, наравно, нису довољне да оспособе наставнике за препознавање специфичности различитих проблема, али јасно сугеришу значај васпитне улоге школе, било да се говори о потреби развијања општих индивидуалних компетенција, интерперсоналне и интраперсоналне интелигенције, или емоционалне интелигенције, то јест о потреби да се деци помогне да посматрају себе и друге, како би открила и научила да користе своје потенцијале, те на тај начин била мотивисана да уче.

Пјер Вијанен $(2006,12)$ уочава сличан „фатализам“ у вези са схватањем интелигенције и мотивације - обично се сматра да њих или има, и тада им се приписује магична моћ, или нема, и тада је наставник немоћан. Интелигенција и мотивација се, међутим, како све чешће читамо у стручној и другој литератури, могу „покренути“ и развијати, највише стварањем услова који доводе до активног учешћа ученика, до његовог когнитивног и емоционалног ангажовања, до осећаја компетентности у нечему па самим тим и самопоуздања, као и осећаја прихваћености, припадања вршњачкој групи у школи, породици и др. Утичући на спољашње факторе мотивације, наставник помаже ученику да пронађе задовољство у учењу, односно буди његову унутрашњу мотивацију. 
Једна од идеја које у овом раду прихватамо и заступамо јесте да је вишеструко корисно, још у раној или почетној настави страног језика, предлагати активности у којима би ученици испољили своје особине и понашање, ${ }^{5}$ односно доминантну интелигенцију, како би наставник могао да на основу уоченог осмисли потоње активности, односно како би знао како које ученике може да мотивише за рад. Уколико могућности за овакве активности не постоје у оквиру редовне наставе, могле би се осмислити радионице. Пригодни предлошци би већ почетно могли да подстакну ђаке, употреба матерњег језика уз страни била би сасвим оправдана на првим часовима, а веома значајно би било охрабривање ученика да не одустане приликом прве препреке - пожељно је навести га да сам открије да је разлика у томе што не улаже свако исти напор за исти резултат у свим доменима.

Предности и мане хетерогених разреда углавном више нису тема око које се споре психолози и дидактичари. С друге стране, остаје отворено питање да ли, у настави страног језика (и иначе), треба давати задатке различите тежине или пак исти задатак за све. Тамо где постоји осетна разлика у језичком нивоу, прво решење је боље, иначе, могуће је и потребно је, нарочито у почетном учењу језика, предложити више могућих приступа истом задатку и комбиновати их. Оваквим поступањем, сматра Гарднер (2014), наставници вишеструко добијају: не само да практикују индивидуализовано учење којим, с једне стране, омогућавају ученицима да открију сопствени начин најефикаснијег учења, али и да развијају интелигенције које им „природно нису најјаче“, него, с друге стране, и сами упознају дете, и, коначно, и сами обогаћују своју праксу и компетенцију да на неколико могућих начина приступе истом задатку, чиме, закључујемо, и сами

5 Интровертно/екстровертно понашање и слично, „у интеракцији са другима и као слику коју градимо о себи и другима“ (3EО 2003, 20), што се све узима у обзир у настави страног језика, будући да „комуникативне активности корисника/ ученика нијесу само производ њихових знања, разумијевања и склоности, већ и одређених личних фактора својствених особинама самих личности које карактеришу склоности, мотивација, вриједности, веровања, когнитивни профил и тип личности који чине идентитет неке особе“ (ЗЕО $2003,119)$, наводе аутори Оквира у поглављу 5.1.3 посвећеном „испољавању и особинама личности“" (savoir-être). 
бивају мотивисани и налазе решење за недовољно задовољавајуће резултате. Успех наставе у XXI веку, закључује Гарднер, управо зависи од способности наставника и читавог образовног система да нађу што бољи одговор на изазов који пред њих постављају одељења с ученицима различитог порекла, матерњег језика, стилова учења, способности - когнитивних, физичких и социоафективних, „које је свако развио на различит начин и не у истој мери, а које чине слику интериндивидуалних разлика“" (Роежје и Де Кетел 2001, 51).

У даљем тексту, бићемо слободни да из угла дидактичара охрабримо будуће и оне већ искусне наставнике да, сналазећи се, користе већ познате технике интеркултурног приступа, предлажу активности у којима би учествовали сви ученици, не само тзв. „маргинализовани“ и не само „талентовани“, не заборављајући на потребу доживотног усавршавања, „отворености за учење“ и промишљање своје праксе. Питање на које, дакле, у следећем поглављу дајемо могући одговор јесте - шта би то у настави и учењу страног језика конкретно значило развијати способност „отворености за учење“" (savoir-apprendre), односно како истовремено учити страни језик и развијати емоционалну интелигенцију, свест о томе како се у друштву може избећи положај жртве настојањем да се истовремено буде и умиљат и интелигентан као ,јагње“ из појединих одабраних примера.

\section{II Предлог за инклузивну праксу}

„И данас, после толико година, игра се тај њен чувени балет у ком уметност и воља за отпором побеђују свако зло, па и саму смрт.““ Иво Андрић, Аска и вук ${ }^{6}$

У инклузивној школи, као и у учењу страног језика, пожељно би било сензибилизовати ученике за посматрање задатака из позитивне перспективе: задатак је игра и изазов, (забавно) решавање проблема,

6 Избор из збирке приповедака Децьа (Андрић 1978), у који је ушла и „Аска“, постоји и на француском језику, у преводу Алена Капона. 
а не претња и неправда, што би такође значило да је процес решавања битнији од резултата. Будући да, у овом раду, првенствено имамо на уму мотивисаније ученике основне школе, са знањем француског језика бољим од просечног, као пример могућег предочавања ученицима појма „учење као изазов“, предлажемо за шести разред (и шесту годину учења, језички ниво А2) активности засноване на четири аудиовизуелна/ аудио/ писана аутентична документа (чији ћемо избор додатно образложити у следећем поглављу). Крајњи циљ била би, рецимо, поставка изложбе ученичких радова - цртежа, стрипова, песама и слично, по избору, инспирисаних радом на документима на тему „снаге“ и „воље“, праћена разговором у вези са изложбом. Идеја је да се подстакне креативност и учешће ученика у колективном пројекту, а надасве осећај компетентности, уз непрестану и благонаклону пратњу наставника приликом извођења овог сложеног задатка и употребу страног језика као средства комуникације. Документима би се испрва приступило ради глобалног разумевања, извлачења кључних мисли и поређења порука, односно остваривања првенствено васпитног циља.

Предлажемо, прво, слушање и гледање видео записа Ла Фонтенове басне о вуку и јагњету (La Fontaine, Le Loup et l'Agneau), затим читање тог текста, с циљем да деца сама препознају поруку - „закон јачега побеђује“, казује већ први стих. Једна од бројних предности рада на овој познатој басни је и та што су је наша деца вероватно већ читала на матерњем, српском језику, што им омогућава да се усредсреде на основну мисао и олакшава им разумевање страног, француског језика. Имајући у виду контекст у којем осмишљавамо дидактизацију басне, и намеру да се од негативне/ "неправичне“" перспективе (ситуације у којој је кажњено невино јагње) стигне до могуће позитивне, при чему би деца износила своја размишљања и могућа решења „изазовних“ ситуација, питања која би ваљало поставити деци јесу, рецимо: Зашӣо

7 Басна би, вероватно, одговарала језичком нивоу А2/Б1 (на интернету постоје предлози за А2 и више разреде основне школе: https:/www.reseau-canope.fr/ langues-en-ligne/uploads/tx_lelextendpages/FLES_Fable_college.pdf, а налази се и у збирци намењеној средњем нивоу - Блондо, Алуаш и Не (2004). Тај језички ниво одговара нивоу уџбеника који се користи у 6. разреду школе В. Рибникар, Фавре и Марјаж (2004), а који издавач одређује као „средњи ниво“. 
УЧЕЊЕ СТРАНОГ ЈЕЗИКА КАО ИЗАЗОВ ЗА „ДРУГАЧИЈЕ ИНТЕЛИГЕНТНУ“ ДЕЦУ И НАСТАВНИКЕ: ИНКЛУЗИВНО ОБРАЗОВАҢЕ И ИНТЕРКУЛТУРНИ ПРИСТУП

је вук морао gа ӣојеgе јайње? Да ли тио чини можgа баш зайо шйо не може gа йоgнесе безазленосии нежне, беле живоииње? Како је јайье мойло ийак gа се сйасе?

Други предложак, поново поучног карактера, треба да пружи ученицима могућност увиђања и другачије перспективе у игри ,јачег“ и „слабијег“, односно очигледније увиђање релативности ових појмова. Опет би се предност дала аудиовизуелној презентацији, која олакшава разумевање, овога пута афричке народне приче о охолој принцези (Une princesse orgueilleuse), ${ }^{8}$ у којој сналажљивост убогог просца, упркос ругању и неверици света, побеђује све богате удвараче, па и охолост лепе принцезе која је коначно проговорила кад је неочекивано мудри удварач нашао начин да је испровоцира и постигне циљ.

Поента трећег предлошка је да „побеђују“ мудрост и лепота, воља и уметност, а реч је о Андрићевој „Аски и вуку“, која се иначе ради на часу српског језика у шестом разреду, што би ученицима такође олакшало разумевање текста понуђеног на француском језику (у скраћеном виду на часу, или, још боље, интегралном код куће, са одломцима на часу).

Духовита љубавна песма Сержа Гензбурга „Cha cha cha du loup“ (Gainsbourg) последњи је предложак који смо замислили у овој серији текстова о вољи, упорности, вештини, уметности и љубави које превазилазе све препреке. Он је првенствено намењен мотивацији деце ${ }^{9}$ са израженијом музичком интелигенцијом, а с циљем да она, између осталог, закључе да се хумором и игром може савладати страх од потенцијалног неуспеха и позиције жртве.

После рада на васпитном циљу, предлажемо да се још мало остане у домену општих индивидуалних компетенција, с постепеним померањем акцента на језичко-комуникативне. То би значило да се прво раз-

8 Видео запис и предлози за рад на причи, која по језичкој тежини одговара нивоу А2 и узрасту 6-12 година, могу се наћи на разним сајтовима, на пример: http://enseigner.tv5monde.com/fle/la-princesse-orgueilleuse (консултовано 13.8.2016)

9 Песми се може приступити и на старијем узрасту, после 16. године, како предлаже Брије (2016) приступајући учењу језика кроз шансону и девету уметност, стрип. Предлог дидактизације се може видети на: https://gallery.mailchimp.com/61c070ceb41816efeeda4da02/files/38_61_lf_ chansons_a60_sbk_web.01.pdf (консултовано 16.8.2016) 
вија интеркултурна и интертекстуална способност ученика, увиђањем не само елемената других култура (на пример франкофоне, афричке, у видео презентацији приче), него и подстицањем поређења (што је иначе активност коју рано интелектуално сазрела деца воле) предложених књижевних текстова, цитата и певане песме с неким другим текстовима, на матерњем или другом језику ${ }^{10}$ у вези са темом изазова и задатка од којег се не одустаје: приче из Малија с нашим народним приповеткама попут „Дјевојка цара надмудрила“ или „Царева кћи и свињарче“, цитата из Андрићеве приче с неким сличним цитатима, Гензбурову песму с неком другом песмом, текстом, бајком о Црвенкапици.

У оквиру лингвистичких компетенција, може се радити на фонолошкој (на прозодији и изговору, на основу звучних записа Ла Фонтенове басне у стиху и приче у којој је очигледан „афрички“ изговор француског језика), на ортоепској (ако би ученицима било занимљиво да гласно читају текст по избору), на социолингвистичкој - језичким регистрима и начинима обраћања (званични код Ла Фонтена: Sire, votre Majesté / фамилијарни и интимни код Гензбура: Ma jolie, ma belle / aгресивни у причи о принцези: Mets donc...!), на лексичкој - асоцијативним пољима за речи попут „снага“ (force), „воља“ (volonté), „уметност“ или „вештина“ (art), „радост живљења“ (joie de vivre), „играти/плесати“ (danser), „разноврсност“" и „различитост“ (diversité).

10 Могли би се, на пример, поредити цитати из Андрићеве Аске и вука:

„И данас, после толико година, игра се тај њен чувени балет у ком уметност и воља за отпором побеђују свако зло, па и саму смрт.“ (Андрић 1978, 196)

«De nos jours encore, après tant d'années, reste inscrit au répertoire son fameux ballet qui voit l'art et la volonté de résistance triompher de tout mal, et même de la mort. » (Андрић 2002, 86)

„Аска није мислила ништа. Само је из свог малог тела, које је било саткано од чистих сокова животне радости а осуђено на неминовну и непосредну смрт, извлачила неочекивану снагу и невероватну вештину и разноликост покрета. Знала је само једно: да живи и да ће живети док игра, и што боље игра. И играла је. То није више била игра, него чудо.“ (Андрић 1978, 192)

" Aska ne pensait à rien. Seules, une force inattendue, une habileté incroyable et diversité de mouvements sortaient de son petit corps fait de l'élixir de la joie de vivre mais condamné à une mort inévitable et immédiate. La seule chose qu'elle savait c'est qu'elle était vivante et qu'elle vivrait tant qu'elle dansait, et le mieux possible. Ce n'était plus une danse mais un miracle.» (Андрић 2002, 82) 
УЧЕЊЕ СТРАНОГ ЈЕЗИКА КАО ИЗАЗОВ ЗА „ДРУГАЧИЈЕ ИНТЕЛИГЕНТНУ“ ДЕЦУ И НАСТАВНИКЕ: ИНКЛУЗИВНО ОБРАЗОВАҢЕ И ИНТЕРКУЛТУРНИ ПРИСТУП

У оквиру прагматичких компетенција, мислимо да би било корисно радити на наративно-дискурзивној компетенцији, на анализи књижевних родова басне (fable), приче и бајке (conte), не само ради препознавања него највише због развијања способности приповедања, у усменом или писаном облику. Будући да се обраћамо мотивисаним и напреднијим ученицима који француски језик уче од првог разреда основне школе, било би занимљиво радити и на иначе запостављеној медијацији, на пример превођењу цитата из Андрићеве приче на француски а затим поређењу са објављеним преводом, или резимирању приповетке на француском језику. Поједини савремени дидактичари сматрају да је ове захтевне активности могуће предлагати још од почетног нивоа А2, прво у усменом виду (нпр. неформално превођење јеловника за француке посетиоце), затим и у писаном, на вишем нивоу Б2 (резимирати чланке из француких новина и часописа) (Розен и Рајнхард 2010: 45). Ове би активности, с једне стране, наставницима и истраживачима могле пружити прилику да се уоче бенефити раног учења страног језика, или да се потврди оправданост изостанка активности медијације у највећем броју уџбеника намењених овом узрсату, а с друге стране, појединим ученицима могу представљати подстицајан изазов, другачији од уобичајених школских задатака.

\section{III Избор предложака и активности за „рано интелектуално сазрелу децу“}

Наш избор текстова који припадају писаној или усменој књижевности, или шансони, ради развијања ученичких прво општих способности („учење учења“, плурикултурна, интеркултурна), паралелно са језичко-комуникативним (на које би се акценат ставио у другој фази рада), и сензибилизације за „различитост“, „релативност снаге“ и „изазовно решавање проблема“, односно ради мотивисања за учење страног језика и то у групи различите деце, нимало није само ствар личног афинитета. Уверење да је на почетку учења страног језика у основној школи од примарног значаја развијати „културно-уметничку“ компетенцију подвлаче не само познати дидактичари (Порше и Гру 1998, 99), него и аутори појединих савремених уџбеника, попут 
аутора уџбеничког комплета VITAMINE, намењеног деци од 7 до 10 година (Мартен и Пастор 2009, 25). Они такође истичу да је веома важно поштовати различитост личности и начин учења свих ученика, развијати све „интелигенције“, „базичне способности“. Активности које они стога предлажу омогућавају ученицима развијање „културно-уметничке“ компетенције, што значи не само развијање способности усменог изражавања и препознавања културно-уметничких елемената, него и развијање прагматичке способности да сами нешто направе или ураде, ослобађајући своје музичке, цртачке, плесне, позоришне, књижевне потенцијале. Уклопљене у сложене, колективне задатке (пројекте), који имају конкретно оваплоћење у виду изложби или представа, ове активности код ученика буде задовољство што могу себи и другима да покажу да су у стању да нешто кажу и направе на француском језику. ${ }^{11}$

Сматрамо да су овакви уџбеници добро решење за малобројне школе у којима постоји могућност да се страни језик интензивно учи још од првог разреда и које свакако међу ученицима имају децу са високим потенцијалом. Карактеристике ових ђака наводимо позивајући се на психологе Факшен (2015) и Револа (2015). Револ, између осталог, упозорава на то да шести разред (за који смо изнели предлоге у претходном делу текста) може представљати прекретницу у односима са другима. Наставници би требало да имају на уму следеће одлике ове деце:

- одлично усмено изражавање (али, нарочито код дечака, не и писано), односно наглашена вербално-језичка интелигенција;

- радозналост, емпатичност, преосетљивост, велика емоционална и чулна пријемчивост, увиђање детаља - ова деца другачије виде свет, као кроз микроскоп, виде све и то увећано, често нереално доживљавају стварност па самим тим дешава се да непоуздано расуђују; - анксиозност и потреба за контролисањем, што такође води њи-

11 Из наставникове перспективе, а саобразно акционој перспективи учења страних језика, остварују се језичко-комункативни и опште-образовни циљеви, кроз индивидуализовано и колективно учење, на подстицајним и најчешће духовитим предлошцима попут прича, бајки, басни, стрипа, песме, бројалице, цртежа. Креативни задаци у овом уџбенику предвиђају: прављење стрипа, фигура, плаката, персонализоване фасцикле, а предвиђено је и извођење скечева, драматизација, имитирање, изражајно читање, уз разне друге игре које учење највећем броју ученика чине забавним и пријатним. 
ховој потреби да им се благонаклоно поставе границе;

- изразита креативност, духовитост, непредвидивост сјајних и бројних идеја, брзо размишљање и разгранатост мисли, више одговора на један задатак, због чега воле отворена питања а сами често постављају атипична, или дају неочекиване одговоре;

- склоност ка индивидуалним играма и спортовима, будући да је комуникација са другима за њих компликована.

Познавање доминантних особина ове групације води опредељењу да се приликом осмишљавања почетних и других активности стави нагласак на вербално-језичку интелигенцију, што на часу страног језика и јесте најприродније решење, односно да се предлажу активности које ће им улити потребно самопоуздање уједно будећи њихову радозналост. То би могле бити активности које:

- што чешће подразумевају читање, слушање или „причање приче“, дословно или у смислу стављања одређене активности у контекст, у „причу““, замислити причу помоћу које ће ученик из позитивне перспективе прићи задатку;

- затим интегришу и друге „интелигенције“, првенствено оне блиске уметности: музичку, телесно-кинестетичку, визуално-просторну - нпр. осмислити или преузети активност са неког сајта с омиљеним дечјим песмама из разних крајева света који уједно промовише мултилингвизам и мултикултурализам;

- имају и колективну димензију, која иначе често прати „уметничке“ активности, те ће се на тај начин „у обланду“ увити колективни рад који овој деци мање прија (а потребан им је), приликом којег деца уче да помажу једна другој и развијају интерперсоналну интелигенцију;

- подразумевају и објашњење смисла извођења задатка, што је нарочито важно овој групи ученика који увек желе да разумеју и да пронађу смисао, да контролишу, односно предност дају питању „зашто“ у односу на метод и питање „како“;

- предлагати им што чешће активности с аналогијама, повезивања по одређеном критеријуму, на пример проналажење текстова, видео записа, песама и слично;

- обавезно мобилишу ученикову креативност и духовитост, воде отвореним питањима, поспешујући развијање дивергентне мисли; поводом приче о охолој принцези то би значило, рецимо, дати задатак 
да се замисле још неке стратегије којима би сиромашни и ружни просац могао освојити принцезу, односно учити децу да се не задовољавају једним јединим решењем или одговором (предлажући им да што чешће замисле другачији крај или наставак неке приче, на пример).

На основу истраживања рано интелектуално сазрелих ученика, психолози, такође, саветују да са овом децом треба избегавати оно што не воле, као што су репетитивне активности или образлагање начина на који су дошли до неког решења, али не увек - иако не воле колективне активности, рецимо, потребно их је укључивати у групни рад (који развија емоционалну и друштвену интелигенцију).

На крају излагања о могућностима рада са интелектуално рано сазрелим ученицима, истакли бисмо потенцијалну „терапеутску“ функцију употребе страног језика, која не само да не „блокира“ ову иначе осетљиву децу, него, напротив, поспешује откривање мисли и осећања, те ученици неретко на страном језику смелије говоре о себи него на матерњем. Стога је, сматрамо, једна од најподстицајнијих и најкориснијих активности - аутопортретисање, у разним видовима, за које се примери могу пронаћи у савременим уџбеницима и на сајтовима за учење француског језика. ${ }^{12}$

\section{IV Уместо закључка: образовање наставника за различитост и прилагодљивост}

На крају рада, чини нам се логичним да истакнемо значај образовања наставника за различитост.

Пратећи редослед излагања у тексту, закључили бисмо да је код (будућих) наставника:

- потребно развијати свест о томе да је значајно посматрати различитост у одељењу као богатство а не проблем (што су базичне претпоставке инклузивног, али и интеркултурног, плурикултурног и

12 На пример за ниво A1, децу од 8 до 11 година, чак и ону која још не читају, може се предложити да нацртају свој аутопортрет, па да га онда усмено изложе, док би читачи могли и да напишу своју „личну карту“. Од аутопортрета ученика може се такође направити заједнички „аутопортрет“ разреда, у виду засебне књижице са цртежима, фотографијама, текстовима. Идеја пронађена на сајту: http://enseigner.tv5monde.com/fle/les-autoportraits-atelier-3-francaislangue-etrangere (консултовано 16.8.2016) 
плурилингвалног приступа у настави страног језика),

- да је неопходно посматрати ученике како би се увидела њихова различитост,

- да свим ученицима треба омогућити да са задовољством уче, подстицањем њихове мотивације и самопоуздања (рецимо применом начела теорије вишеструких интелигенција), као и укључивањем у екипни рад.

Наставнике, такође, увек треба да води свест о „прилагодљивости““, у свему што се тиче групе ученика коју има пред собом, што значи при избору:

- разноврсних метода,

- времена потребног за израду задатка,

- предложака за рад,

- уџбеника које би могли да користе сви ученици,

- креативних активности, које што чешће подразумевају и физичку активност.

Важно је будуће наставнике упућивати и у стратегије охрабривања ученика и позитивног односа према грешци, тако што ће ученицима указивати на већ добре, остварене резултате, употребом прикладних речи које ученике „вуку напред“ (на пример, боље је говорити „кад у томе будем/ш успео“, него „ако у томе будем/ш успео“), уз стално присутну мисао о наредној фази коју је потребно предложити да би ученик напредовао.

Заправо је најважније развити свест о томе да се савремена улога наставника (који прихвата идеју о вишеструким интелигенцијама ученика) веома разликује од традиционалне, трансмисивне - савремени наставник (тек) на крају часа или серије часова експлицира, сажима и обликује ученичка открића и сазнања, до којих се дошло у интеракцији различитих интелигенција и способности, применом различитих а групи прилагођених предложака, активности, метода и облика рада.

Нова наставникова улога у инклузивном образовању тражи од њега и да буде вешт познавалац нових технологија, које му могу бити одличан (али не искључиви) савезник у откривању ученичких склоности и осмишљавању подстицајних активности.

У иницијалном и континуираном образовању, наставник треба 
такође да учи како у „новој“ школи да дође до извора који му могу помоћи да реши одређени проблем, коме да се обрати за помоћ и с ким треба да сарађује, али и како да самом себи подигне самопоуздање.

Допринос инклузивној пракси који би могли да пруже методичари наставе страних језика у факултетској настави огледао би се, пре свега, у настојању да код будућих наставника развију неопходна знања о инклузивном образовању, позитивне ставове и свест о неопходности доживотног учења. Међутим, као што постоје оправдана очекивања од универзитетских наставника који образују будуће наставнике страног језика, постоји и чињеница да дуга теоријска настава на факултету и кратка методичка пракса не решавају конкретне проблеме. Стога се решење види у сталном и практичном усавршавању, повезивању више сродних приступа (као што су интеркултурни и инклузивни), као и у „хоризонталној сарадњи између различитих актера у области инклузије: универзитета, министарства, школа и других образовних установа за наставнике“ (Холенвегер 2015, 5).

\section{Литература}

\section{Референие}

Абдала-Претсеј 2004: Martine Abdallah-Pretceille. L'éducation interculturelle. Paris : Presses Universitaires de France.

Абдала-Претсеј и Порше 2001: Martine Abdallah-Pretceille ; Louis

Porcher. Éducation et communication interculturelle. Paris : Presses

Universitaires de France.

Бут и Ејнскоу 2010: Tony Booth; Mel Ainscow. Приручник за инклузивни развој школе: Уйотиреба иняекса за инклузију за развој инклузивне кулйуре, йолиииике и йраксе. Београд: Save the Children, Завод за вредновање квалитета образовања и васпитања.

Вијанен 2006: Pierre Vianin. La motivation scolaire : Comment susciter le désir d'apprendre? Bruxelles : De Boeck \& Larcier s.a.

Гарднер 1983: Howard Gardner. Frames of minds: the Theory of Multiple Intelligence. New York: Basic Books.

Гарднер 2014: Howard Gardner. " Entrevue avec Howard Gardner. » 
Konsultovano 10.8.2016. http://apprendreaeduquer.fr/intelligencesmultiples-gardner/.

Де Карло 1998: Maddalena De Carlo. L'interculturel. Paris : CLÉ International. Дурбаба 2011: Оливера Дурбаба. Теорија и иракса учења и насйаве сиираних језика. Београд: Завод за уџбенике.

Зарат 2003: Geneviève Zarate. Médiation culturelle et didactique des langues. Strasbourg : Conseil de l'Europe, Centre européen pour les langues vivantes.

Пирен 2002 : Christian Puren. « Perspectives actionnelles et perspectives culturelles en didactique des langues-cultures: vers une perspective co-actionnelle co-culturelle. » Konsultovano 5.8.2016. http://www. christianpuren.com/mes-travaux/2002b/.

Порше и Гру 1998: Louis Porcher; Dominique Groux. L'apprentissage précoce des langues. Paris: Presses universitaires de France.

Револ 2015: Olivier Revol. «L'enfance des surdoués. » Konsultovano 5.8.2016. https://www.youtube.com/watch? $\mathrm{v}=\mathrm{Rd}$ 8pow-2qb4

Робер 2009: Jean-Michel Robert. Manières d'apprendre. Pour des stratégies d'apprentissage différenciées. Paris : Hachette.

Роежје и Де Кетел 2001: Xavier Roegiers; Jean-Marie De Ketele. Une pédagogie de l'intégration : Compétences et intégration des acquis dans l'enseignement. Bruxelles : De Boeck \& Larcier s.a.

Розен и Рајнхард 2010: Évelyne Rosen; Claus Reinhardt Le point sur le Cadre européen commun de référence pour les langues. Paris : CLE International.

Савет Европе 2003: Savet Evrope. Zajednički evropski okvir za žive jezike: učenje, nastava, ocjenjivanje. Podgorica: Ministarstvo prosvjete i nauke.

Факшен 2015: Jeanne Siaud Facchin. « Ces drôles de zèbres. » Konsultovano 6.8.2016. http://www.franceculture.fr/emissions/sur-les-docks/ces-drolesde-zebres.

Холенвегер 2015: Judith Hollenweger. Alat za unapređenje prakse obrazovanja nastavnika za inkluzivno obrazovanje. Brisel, Strazbur: Evropska unija, Savet Evrope.

Шародо 1987: Patrick Charaudeau. « L'interculturel : nouvelle mode ou pratique nouvelle? » Le Français dans le monde, numéro spécial, $25-33$. 
Консулимован настиавни майеријал

Андрић 1978: Иво Андрић. Децุа. Прийовейке V. Београд: Просвета/ Загреб: Младост/Сарајево: Свјетлост/Љубљана; Државна заложба Словеније/Скопје: Мисла.

Андрић 2002: Ivo Andritch. Innocence et châtiment: nouvelles, trad. du serbo-croate et postf. par Alain Cappon. Bruxelles / Paris: Éd. Complexe.

Блондо, Алуаш и Не 2004 : Nicole Blondeau ; Ferroudja Allouache ; Marie-Françoise Né. Littérature progressive du français (niveau intermédiaire). Paris : CLE international.

Брије 2016: Geneviève Briet. La France des années 60 en chansons : Jacques Brel, Gainsbourg. Paris: Éditions Maison des Langues. Димон 2007: Jean-François Dumont. La petite oie qui ne voulait pas marcher au pas. Paris : Editions Flammarion.

Клајс 2014: Michel Claeys Bouüaert. Éducation émotionnelle, de la maternelle au lycée. Gap: Souffle d'Or.

Мансо 2008: Édouard Manceau, Tous pareils! petites pensées de sagesse caribou. Toulouse : Éditions Milan.

Мартен и Пастор 2009: Carmen Martin; Dolorès Pastor. Vitamine 1.

Guide pédagogique. Paris : CLE International.

Пap 2006: Todd Par. Tous différents! Paris : Bayard Jeunesse.

Фавре и Марјаж 2004: Catherine Favret ; Aline Mariage. Oh là là ! 3. Paris : CLE International. 


\title{
Jelena Brajović
}

\author{
L'APPRENTISSAGE D'UNE LANGUE ÉTRANGÈRE \\ COMME DÉFI POUR LES ENFANTS \\ «DIFFÉREMMENT INTELLIGENTS» \\ ET LES ENSEIGNANTS: ÉDUCATION INCLUSIVE ET \\ APPROCHE INTERCULTURELLE
}

\begin{abstract}
Résumé
Ce texte traite des élèves intellectuellement précoces (EIP), sans doute nombreux dans l'apprentissage précoce des langues étrangères et représentatifs de tous les autres élèves différents et souvent en difficulté sur le plan scolaire. Comme il est très important pour les enseignants de français langue étrangère (FLE) de mieux connaitre les spécificités des EIP pour pouvoir proposer des ressources et des adaptations pédagogiques, un chapitre entier y est consacré, contenant des pistes pour accompagner des enfants à haut potentiel, suivi d'un autre soulignant l'importance de la formation des (futurs) enseignants de FLE pour l'école inclusive, tout au long de la vie, et du changement de posture pédagogique. Ayant pour objectif de donner des exemples concrets pour une possible exploitation des supports artistiques dans une classe de FLE pour les enfants de 12 ans et de niveau A2, et d'encourager des enseignants qui se sentent esseulés et démunis face à l'inclusion dans une classe ordinaire, l'article met en évidence les mêmes principes de base de l'éducation inclusive et de l'approche interculturelle, axées vers la diversité comme un défi.
\end{abstract}

Mots-clés : éducation et formation inclusives, approche interculturelle, élèves intellectuellement précoces, diversité, français langue étrangère. 